\title{
EXTENT OF GENETIC VARIABILITY CREATED THROUGH BIPARENTAL MATING IN COTTON (Gossypium barbadense
} L.) Abdel-Moneam, M.A.*; M. H. Ghoneima*; Y. M. EL- Mansy** and M. W. EL-Shazly**.

*Dept. of Agronomy, Fac. Agric., Mansoura Univ., Egypt. ${ }^{* *}$ Cotton Res. Institute, Agric. Res. Center, Egypt.

\section{ABSTRACT}

A study was undertaken in cotton (Gossypium barbadense, L.) to assess the relative efficiency of biparental mating and $\mathrm{F}_{3}$ selfed populations in realizing greater variability with desirable recombinants using $F_{2}$ of two crosses viz. (Giza 89 × PS6) × 6022 and Giza 92 × Pima $\mathrm{S}_{6}$. These $\mathrm{F}_{2}$ populations were advanced to $F_{3}$ following intermating of biparental mating (BIP) and selfing. The two populations thus developed in each of two crosses were then evaluated for earliness, yield and fiber quality characters. Analysis of variance revealed highly significant differences among biparental sets of families for all studied characters. The variation between plants in biparental progenies were relatively high as compared with $\mathrm{F}_{3}$ selfed families. Biparental progenies proved its superiority over selfing by registering high mean values in desirable direction for most characters. In general, the lower limits of range were lower for earliness characters in biparental progenies, at the same time it were high for yield and fiber characters.

Considerable variation was observed in biparental progenies as compared to $\mathrm{F}_{3}$ selfed populations for most of the characters, which confirmed by high mean genotypic coefficient of variation (GCV) and phenotypic coefficient of variation (PCV) values. The variation created on account of biparental mating was found to be heritable as seen from increases of discrepancy between (PCV) and (GCV) and reflected less influence of environmental factors.

The contribution of additive variance was higher than the non additive variance for most earliness characters, lint percentage, lint index and uniformity ratio in both BIP and $\mathrm{F}_{3}$ selfed populations. The magnitude of nonadditive were largely estimated in BIP for most yield characters, fiber fineness and strength in both crosses as compared with $F_{3}$ selfed. Broad sense heritability improved considerably for most characters in BIP because of the increase of genetic variance to the total phenotypic variance due to cryptic genetic changes that have been brought about one cycle of intermating.

Keywords: Cotton, Biparental mating, PCV, GCV, Genetic variance.

\section{INTRODUCTION}

Creation of variability using proper breeding procedures is pre-requisite either for development of varieties or inbred lines. Generally, the amount of variability generated is more noticeable in the early segregating generations as compared to later generations. In Egyptian cotton (G. barbadense L.), since selection within local materials has been going on far a long time, the genetic variability have been decreased exhausted. Further, breakthrough in productivity will have to come from controlled crosses designed to creat new 
and wide variability. Conventional breeding methods like pedigree, bulk and back crossing methods with some modifications impose restrictions on the chances of better recombination's because of larger linkage blocks associated with the weakness of causing rapid homozygosity and low genetic variability (Rudra et al., 2009). Further negative association among yield components and high genotype by environmental interaction prevent full exploitation of genetic variability for characters like yield. Biparental mating among the segregants in the $\mathrm{F}_{2}$ of a cross may provide more opportunity for the recombinations to occur, mop up desirable genes as a result release concealed variability (Pradeep and Sumalini, 2003). Biparental mating, It's a useful system of mating for generation of increased variability and may be applied where desired variation for traits of interest is lacking ( Guddadamath et al., 2010 and 2011).

Very few researchs were applied by using biparental mating in cotton. Tyagi (1986) indicated that the biparental intermated was more amenable to improve through selection than $F_{3}$ selfed. Abo Arab (2000), Soliman (2003) and Abd El-Salam (2005) cleared that biparental mating system was more effective in breaking undesirable linkages. On the other side, many researchers pointed out that several cycles intermating population may be useful for exploitation both type of gene effects, additive and non additive. Such strateg will help to increase frequency of favourable alleles (EL-Mansy ,2005 ; EL-Mansy et al., 2010 and Hamoud et al., 2013).

In view of the obove facts, an attempt has been made in the present study to create and assess the different pattern of variability in the biparental progenies for its use in improving yield and fiber quality in cotton and to compare it with $\mathrm{F}_{3}$ selfed generation.

\section{MATERIALS AND METHODS}

The experimental materials for the present investigation were comprised of $\mathrm{F}_{2}$ generation of two single crosses i.e (Giza $89 \times$ Pima $\mathrm{S}_{6}$ ) $\mathrm{x}$ 6022 and Giza 92 x Pima- S6. About 48 plants were selected in each $F_{2}$ population on visual basis keeping in view the vigour for selective intermating. The $F_{2}$ plants were devided into 16 male plants and 32 female plants, for each cross, one male was crossed with two female. The $F_{2}$ plants used in biparental mating were also selfed to yield $\mathrm{F}_{3}$ progenies. Thus 32 biparental progenies and $48 \mathrm{~F}_{3}$ selfed were developed.

The experiment was conducted at Sakha Agric. Res. Stat. Kafr ELSheikh, Agric. Res. Center Egypt, during 2010 and 2011 growing seasons. The BIP progenies and their corresponding $F_{3}$ populations with their original parents were evaluated at a randomized complete blocks design with three replicates with a row length of $4.0 \mathrm{~m}$. The rows and plants were spaced at 70 $\mathrm{cm}$ and $30 \mathrm{~cm}$ respectively. All recommended package practices were applied during the growing seasons. The data were recorded on six guarded plants in BIP and $\mathrm{F}_{3}$ selfed for each cross including; first fruiting node (F.F.N), days to first flowering (D. F. F), growth period duration (G.P.D), boll maturation period (B.M.P), boll weight in grams (B.W), seed cotton yield per 
plant in grams (S.C.Y), lint yield per plant in grams (L.Y), lint percentage (L.P $\%$ ), seed index in gm (S.I.), lint index in gm (L.I.), fiber fineness (F.F.) as micronaire reading, fiber strength (F.S) as pressley index, uniformity ratio (U. R.) and fiber length (F.L.) as $2.5 \%$ span length.

\section{statistical analysis}

The data were subjected to statistical analysis of variance outlined by Comstock and Robinson (1952), and developed by Kearsy and Pooni (1996), and Singh and Pawar (2002), (North Carolina Design-l). The mean and ranges in respect of each characters were calculated in the biparental as well as $\mathrm{F}_{3}$ progenies. The phenotypic and genotypic coefficient of variations were also calculated. Heritability in broad and narrow senses were obtained in biparental progenies and $\mathrm{F}_{3}$ selfed populations according to Kearsy and Pooni (1996), as formula : Heritability in broad sense $\left(\mathrm{h}^{2} \mathrm{~b}\right)=\frac{\sigma^{2} g}{\sigma^{2} P} x 100$ Heritability in narrow sense $\mathrm{h}^{2} \mathrm{n}=\frac{\sigma^{2} A}{\sigma^{2} P} \times 100$

where $\sigma^{2} \mathrm{~g}, \sigma^{2} \mathrm{~A}, \sigma^{2} \mathrm{P}$ refer to genotypic, additive and phenotypic variances respectively.

\section{RESULTS AND DISCUSSION}

Breeders very often use the segregating populations as a source of variability for selection to obtain homozygous recombinant lines with better performance which developed into varieties. Most often the source of $F_{2}$ population due to single cross hybrids and / or double cross hybrids would offer limited opportunities for achieving high success genotypes because of narrow genetic base and impose restrictions on the chances of better recombinants and also associated with the weakness of induction rapid homozygous as well as low genetic variability.

Analysis of variance of biparental sets of families (Table 1) revealed significant or highly significant mean squares among crosses for all studied characters over two crosses indicating the presence of high segregations in $F_{2}$, this variation further transmitted to biparental progenies. Partitioning biparental crosses mean square to male and female within male, mean squares due to males were hig- hly significant for all studied characters and large in magnitude than female within male, which revealed over all differences between $F_{2}$ male parents. However, female within male were also significant for all characters, indicating significant genetic variation. Genetic variation composed of additive and / or non additive, dominance or epistasis, would be necessary to make further improvements in such characters. Similar results were in agreement with Khedr (2002) and EL-Mansy (2005) for earliness characters, Tyagi (1987), Pradeep and Sumalini (2003), for yield characters and May and Cynthia (1994), Zeina (2002) and Hassan (2012) for fiber quality characters. 
Abdel-Moneam, M.A. et al.

1

1284 
Intra-class variability, which due to differences between plants within each family, was marked out for the studied characters in $\mathrm{F}_{3}$ selfed and BIP progenies in Table 2. Generally, high intra-class variability values were recorded in two crosses in both $\mathrm{F}_{3}$ and BIP populations for most yield characters, first fruiting node and boll maturation period, indicating high variability between plants within their $\mathrm{F}_{3}$ and BIP families. However lint percentage, fiber quality, days to first flower and growth period duration showed low intra-class variability, reflecting low variability between plants within each family. The variation between plants in BIP were relatively high as compared with $\mathrm{F}_{3}$ families. This was true, since biparental or intermated between $\mathrm{F}_{2}$ plants creation new variability in population (Ontagodi, 2009).

Segregating populations with high mean are relatively effective in identifying the superior recombinants. A comparison of mean and range of expression of different characters (Table 3 ) between BIPs and $F_{3}$ selfed, indicated that mean values of BIP progenies were higher than mean values of $\mathrm{F}_{3}$ selfed families for most studied characters. These shifting in mean values in desirable direction were clearly pronounced in earliness and yield characters. Desirable mean values of the BIP could largely be attributed to the predominance of additive and Additive $\mathrm{x}$ additive type of gene action of the characters in the intermated populations (Sharma and Kalia, 2003), or / and could also be due to creation of more variability by breakage of undesirable linkages which otherwise concealed the genetic variation in $F_{3}$. Thus superior performance of BIP progenies could mainly be attributed to the possible accumulation of favourable genes in positive direction.

By the comparison between $\mathrm{F}_{3}$ and BIP populations it could be shown considerably higher mean values for most characters, indicating the dominance deviation and epistatic interaction in BIP populations. The mean performance appeared to be improved in respect of seed cotton and lint yield and most earliness and some fiber quality characters in BIP, which can be attributed to exploitation of non-additive gene effects on account of mop up of alleles influencing the characters (Rudra et al., 2009). The estimates of genetic variation make the task of breeder easy, so as to make effective selection. The release of hidden genetic variability by breaking undesirable linkages might be another reason for increasing mean performance and higher variability of biparental populations. The range of an index of variability was wider in biparental progenies as compared to $F_{3}$ progenies for most studied characters. The lower limits of range were lower in biparental progenies for most earliness characters. At the same time, lower limits of range were low in $F_{3}$ progenies for yield and fiber quality characters as compared to BIP, leading to wider spectrum of variability, suggesting that intermating has helped in releasing hidden variability. However, the reduced variability in BIP for some characters could be due to presence of genes controlling such characters in coupling phase, Vinayan and Govindrasu (2010), probably a few more cycles of intermating would result in breaking the linkages and thus releasing more variability. 
Abdel-Moneam, M.A. et al.

2 
General shifts in the values of range of characters by biparental approach were also reported by Pradeep and Sumalini (2003), Guddadamath et al. ( 2011 ) and Hassan ( 2012 ).

The estimates of Genotypic and phenotypic coefficients of variability (Table 3) revealed that PCV \% and GCV\% were larger in magnitude for most studied characters in both crosses over both BIP and $F_{3}$ selfed, indicating that magnitude of genetic variability which presented in these materials was sufficient for providing rather substantial amount of improvement through selection of superior progenies. Also data indicated slight discrepancy between PCV\% and GCV\% for most characters which indicated less influence of environment in the expression of these characters (El-Lawendey, 2003 and Kapoor and Kaushik, 2003). The comparison of GCV and PCV in intermated and $\mathrm{F}_{3}$ selfed populations for the studied characters (Table 3), indicated that the estimates of PCV were generally higher than GCV for all of the characters. This may be due to the involvement of high genotypic $x$ environmental interaction effect in character expression (Kaushik et al., 1996). The present study brought out the existence of higher genetic variability in BIPs than $\mathrm{F}_{3}$ selfed populations for most of the characters in both the crosses. The increased genetic variability in BIP due to intermating of $F_{2}$ plants. This could be attributed to the fact that biparental mating in $\mathrm{F}_{2}$ generation forced the new recombinations, thereby undesirable linkages, especially in repulsion phase were broken down, which resulted in the release of hidden genetic variability. The overall effects produced greater genetic variability in BIP population than normal $F_{3}$ selfed populations. The reduced variability in BIP particulary for boll weight and uniformity in the second cross, fiber length and uniformity ratio in the first cross would be due to presence of genes controlling these characters in coupling phase (Vinayan and Govindarasu, 2010).

Among the characters, in all populations, GCV and PCV were high for seed cotton and lint yield / plant followed by boll weight, lint index, fiber fineness and fiber strength. This may be attributed to the predominance of ruplsion phase linkage. Kampli et al. (2002), reported high GCV and PCV for some characters, this may be attributed to their highly diverse in nature and increased opportunity for favourable recombination of genes in $F_{2}$ population. The remained characters show lower GCV and PCV values. Ge et al. (2008) and Araujo et al. (2012), reported that the lowest CV values were associated with variables representing the quality of the fiber, is due to the smaller number of genes influencing their response.

In the case of biparental progenies, the controbution of additive component of genetic variance (Table 4) was higher in respect of most earliness characters, lint percentage, lint index, fiber uniformity in both crosses. 
Abdel-Moneam, M.A. et al.

3 
J. Plant Production, Mansoura Univ., Vol. 4 (9), September, 2013

4

1289 
Abdel-Moneam, M.A. et al.

4

1290 
J. Plant Production, Mansoura Univ., Vol. 4 (9), September, 2013

4

1291 
Abdel-Moneam, M.A. et al.

With respect to $\mathrm{F}_{3}$ selfed populations, all earliness characters, lint percentage, lint index and all fiber quality characters were under control of additive genetic variance. Similar results were obtained by Abd El-Bary (2003), Karademir et al. (2009) and Natera et al. (2012) .

However the magnitude of non-additive were largely in BIP for first fruiting node and growth period duration in the first cross, most yield characters in both crosses and fiber fineness and strength in both crosses as compared with $\mathrm{F}_{3}$ selfed. These could be emphasized by dominance ratio, which was more than unity and showed the importance of over dominance gene effect in the genetic control of these characters, and indicated that non fixable genes could be exploited efficiency through hybrid breading method for improving such characters. In this respect lqbal et al. (2006), Khan et al. (2009), Mohamed et al. (2009), Abd El-Salam et al. (2010) and ElMansy et al. (2012) found similar results.

It is interest to note that, estimation of additive and non-additive components of variance is reliable in advanced generations. Estimates of additive genetic component from advanced generations would be more reliable than those from the corresponding $F_{2}$ generation. Since estimates from $F_{2}$ might be biased in the presence of repulsion phase linkages, which over estimate non-additive variance and may therefor, conceal additive variation. These effects could be dissipated in biparental mating. If this proposition holds true, superior recombinants should be expected in the progenies of biparental matings compared with selfed progenies (Ontagodi, 2009), so the biparental mating system is very much helpful in breaking the repulsion phase linkage and estimates of variance components are reliable.

Comparison of heritability estimates between biparental progenies and selfed population revealed that, heritability estimates in broad sense $\left(\mathrm{H}^{2} \mathrm{~b} \%\right)$ improved considerably for most characters in biparental. Most characters showed high heritability values over than $50 \%$ in both BIP and $\mathrm{F}_{3}$ selfed. The change of heritability estimates towards higher side in biparental progenies over selfing series occurred probably due to increased portion of genetic variance to total phenotypic variance, due to cryptic genetic change that have been brought about one cycle of intermating. This suggests that variation due to the environment played relatively limited role in influencing inheritance of these characters. Improvement in the heritability values for the studied characters is of particular interest for breeder as it enhances the scope for improved selection response for such characters. High heritability estimates in case of BIP compared to selfed series were also reported by Ontagodi (2009), and Parameshwarappa et al. (2009).

However, reverse trend were obtained with respect to narrow sense heritability $\left(\mathrm{H}^{2} \%\right.$ ) which showed high values in $\mathrm{F}_{3}$ selfed families than biparental progenies for most characters. This was due to great role of additive portion of genetic variance in selfed series. However, in case of 
biparental progenies more of non-additive gene action was observed for most characters. This mainly due to breakage of repulsion phase linkage. High recombination frequency might be due to one season of random mating and that may lead to some cryptic genetic changes within each populations separately. Similar results were obtained by Basal and Turgut (2005), Esmail (2007), Rahman and Malik (2008), and Hassan (2012). However, Murtaza et al. (2002), El-Mansy (2005), Said (2012) and El-Hashash (2013) with respect to low narrow sense heritability controlled yield and fiber characters.

\section{CONCLUSION}

The comparison of biparental mating and selfing show that whatever additional variability realized with biparental mating in the early segregating generations has been the consequence of release of concealed variability in the segregating generation which is probably brought about by rare recombination between the tightly linked genes. In addition to this, it is also expected to help in maintaining a greater variability for selection to be effective for longer period. Cotton is an often cross pollinated crop, where lack of variability has been implicated as one of the important causes for lack of desired progress in breeding. Hence, the present study on the use of biparental mating in an early segregating generation like $F_{2}$ of an appropriate cross, could be of much use in widening variability and consequently in making considerable gain in improving productivity.

\section{REFERENCES}

Abd EL-Bary, A. M. R. (2003). Triallel analysis of some quantitatively inherited traits in Gossypium barbadense L. Ph. D. Thesis, Fac. of Agric. Mansoura Univ., Egypt.

Abd EL-Salam, M. E. (2005). Studies on breeding and maintenance of cotton varieties G. barbadense L. Ph. D. Thesis, Fac. of Agric., Agron. Dept., Kafr EL-Sheikh, Tanta Univ.

Abd EL-Salam, M. E. ; M. A. EL-Ameer and Y. M. EL-Mansy (2010). Factor analysis and its relationship with genetic diversity in cotton. Minufia $j$. Agric. Res., 35 (3): 941-955.

Abo-Arab, A. R. (2000). Using biparental mating system for encouraging desirable recombinations in cotton. Mlnufiya J. Agric. Res., 24 (6): 1999-2014.

Araujo, L. F. ; W. S. de Almeida ; F. C. Neta and E. Bleicher (2012). Correlation and path analysis in components of fiber yield in cultivars of upland cotton. Bragantia, Campinas, 71 (3): 328-335.

Basal, H. and I. Turgut (2005). Genetic analysis of yield components and fiber strength in upland cotton. Asian J. plant Sci., 4 (3): $293-298$.

Comstock, R. E. and H. F. Robinson (1952). Estimation of average dominance of genes. In: J.W. Gowen (Ed.), Hetersois, pp. 494-516. lowa State College Press Ames. 
El-Hashash, E. F. (2013). Heterosis and gene action among single and double cross hybrids performances in cotton. American. Eurasian J. Agric. Environ. Sci., 13 (4): $505-516$.

El-Lawendey, M. M. A. (2003). Effect of some selection procedures on lint yield and seed characters improvement in cotton. Ph. D. Thesis, Fac. Agric., Moshtohor, Zagazig Univ., Egypt.

EL-Mansy, Y. M. (2005). Using genetic components for predicting new recombination in some cotton crosses. Ph. D. Thesis, Fac. Agric., Mansoura Univ., Egypt.

El-Mansy, Y. M. ; M. M. El-Lawendey and M. A. A. El-Dahan (2012). Genetic variabilities in growth habit and development of boll and its related with yield and fiber characters in Egyptian cotton. Egypt. J. plant Breed., 16 (1): $83-97$

El-Mansy, Y. M. ; R. M. Hassan and M. E. Abdel-Salam (2010). Estimation of genetic components and genetic divergence in diallel hybrids of cotton. J. Agric. Res. Kafr El-Sheikh Univ., 36 (1): 17-32.

Esmail, R. M. (2007). Genetic analysis of yield and its contributing traits in two inter specific cotton crosses. J. Appl. Sci. Res., 3 (12): 2075 2080.

Ge. Y. ; J. A. Thomasson, R. Sui and C. B. Parnell (2008). Spatial variation of fiber quality and associated with dry land cotton field. Precision Agric., 9: 181-194.

Guddadamath, S. ; H. D. Mohankumar and K. Sujatha (2010). Genetic analysis of biparental mating and selfing in segregating populations of bhendi. Electronic J. Plant Breeding., 1 (6): 1500-1503.

Guddadamath, S. ; H. D. Mohankumar and P. M. Salamath (2011). Genetic analysis of association studies in segregating population of Okra. Karnataka J. Agric. Sci., 24 (4): $432-435$.

Hamoud, H. M. ; A. M. R. Abd EL-Bary and Y. A. M. Soliman (2013). Detection of epistasis and estimation of additive and dominance components of genetic variance in cotton. The $8^{\text {th }}$ Plant Breed. Int. Conf., 14-15 May 2013.

Hassan, S. S. (2012). Genetical studies on some crosses of (Gossypium barbadense L.) cotton. Ph.D. Thesis, Fac.of Agric. AL-Azhar, Univ, Egypt.

Iqbal, M. ; K. Hayat, R. S. A. Khan and N. Islam (2006). Correlation and path coefficient analysis for earliness and yield traits in cotton (G. hirsutum L.). Asian J. Plant Sci., 5: 341-344.

Kampli, N. ; P. M. Salimath and S. T. Kajjidoni (2002). Genetic variability created through biparental mating in chick pea. Indian J. Genet. Plant Breed., 62 (2): $128-130$.

Kapoor, C. J. and S. K. Kaushik (2003). Variability, heritability and genetic advance studies in cotton (G. hirsutum L.). J. Cotton, Res. Dev., 17 (2): 242-246.

Karademir, C. ; E. Karademir and O. Gencer (2009). Combining ability estimates and heterosis for yield and fiber quality in $L \times T$ Desigenol cotton. Not. Bot. Hort. Agrobo., 37 (2): 228-233. 
Kaushik, S. K. ; S. C. Sharma, I. S. Pawar and G. R. Sharma (1996). Effectiveness of sibmating in wheat breeding. Indian J. Genet. plant Breed., 56: $202-206$.

Kearsey, M. J. and H. S. Pooni (1996). Genetical analysis of quantitative traits. Chapman and Hall, London.

Khan, N. U. ; Gul Hassan; Marwat, K. B.; Farhatullah; SundusBatool; KhadijahMakhdoom ; Imtiaz Khan; Khan, I. A. ; Waqas Ahmad. (2009). Genetic variability and heritability in upland cotton.Pakistan Journal of Botany., (41) : 4, 1695-1705.

Khedr, A. H. (2002). Genetical studies on cotton. Ph. D. Thesis, Fac. Agric., Zagazig Univ., Egypt.

May, O. L. and C. G. Cynthia (1994). Genetic variation for fiber properties in elite peedee cotton populations. Crop Sci., 34: 684-690.

Mohamed, G. I. A. ; Abd-El-Halem, S. H. M. and Ibrahim, E. M. A. (2009). A genetic analysis of yield and its components of Egyptian cotton (Gossypium barbadense L.) under divergent environments, AmericanEurasian J. of Agric. and Environ., Sci. 5 (1): 5-13.

Murtaza, N. ; A. A. Khan and A. Quayum (2002). Estimation of genetic parameters and gene action for yield of seed cotton and lint percentage in G. hirsutum L. J. Res. Bahauddin Zakariya Univ., Multan, Pakistan, $13: 151-159$.

Natera, J. R. ; A. Rondon ; J. Hernandez and M. Pinto. (2012). Genetic studies in upland cotton (G. hirsutum L.) II - General and specific combining ability. J. Agric. Sci. Tech., $14: 617-627$.

Ontagodi, T. P. (2009). Breeding investigation on improving combining ability for exploitation of heterosis in Okra. M. Sc. Thesis, Fac. Agric. Univ. Agric. Sci., Dharwad.

Parameshwarappa, K. G. ; R. Naik and M. Bentur (2009). Impact of biparental mating on genetic variability and path analysis in safflower. Karnataka J. Agric. Sci., 22 (1): $44-46$.

Pradeep, T. and K. Sumalini (2003). Impact of mating system on genetic variability in segregating generations of Asiatic cotton. Ind. J. Genet. plant Breed., 63 (2): $143-147$.

Rahman, S. U. and T. A. Malik (2008). Genetic analysis of fiber traits in cotton. Int. J. Agric. Biol. 10 (2): $209-212$.

Rudra, N . ; M. G. Bentur and K. G. Parameshwarappa (2009). Impact of biparental mating on genetic variability and path analysis in sufflower. Karnataka J. Agric. Sci., 22 (1): 44- 46.

Said, S. E. R. N. (2012). Genetical studies on double crosses in cotton Ph. D. Thesis, Fac. Agric. Tanta Univ. Egypt.

Sharma, A. and P. Kalia (2003). Studies on biparental progenies in garden pea. Indian J. Genet. plant Breed., 63 (1): 79- 80.

Singh, S. and I. S. Pawar (2002). Theory and application of quantitative genetics. New Delhi India.

Soliman, Y. A. M. (2003). Studies on some quantitative characters in some interspecific cotton crosses. Ph. D. Thesis, Fac. Agric., Kafr EL-Sheikh, Tanta Univ., Egypt. 
Tyagi, A. P. (1986). Variability and heritability for yield and its components in Upland Cotton ( Gossypium hirsutum L.). East African Agric. and Forestry. J., 52 (1): 37-40.

Tyagi, A. P. (1987). Correlation studies on yield and fibre traits in upland cotton (Gossypium hirsutum L.).Theo. and Appl. Genet., 74 (2):280283.

Vinayan, M. T. and R. Covindarasu (2010). Relative efficiency of biparental mating, single capsule descent, selected bulk and random bulk selections in sesame. Eloctronic J. plant Breed., 1 (4): 666 - 674.

Zeina, A. M. A. (2002). Using biparental mating system to produce new promising recombinations in cotton. Egypt. J. Agric., Res., 80 (1): 325340.

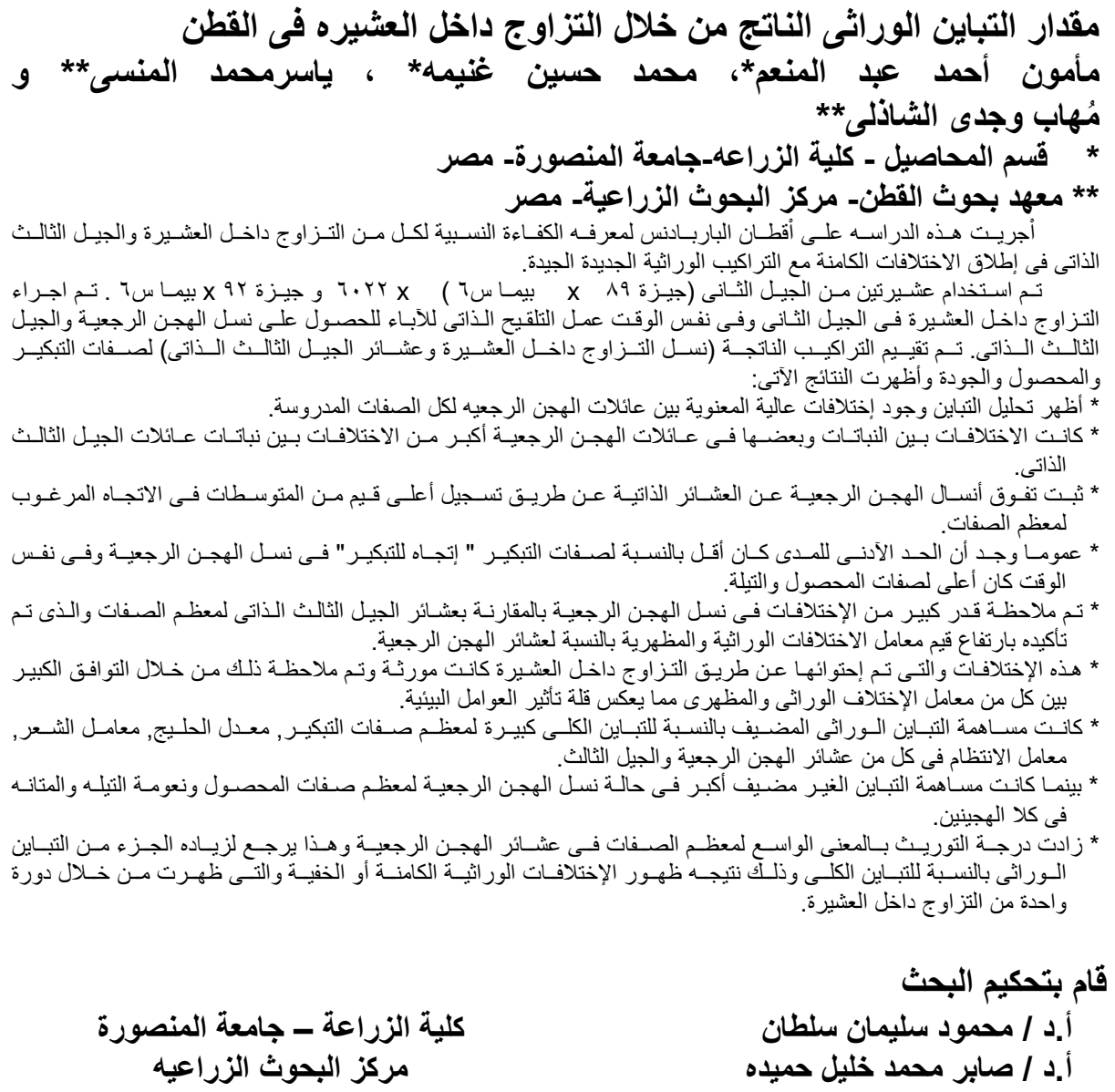


J. Plant Production, Mansoura Univ., Vol. 4 (9): 1281 - 1296, 2013

Table 1 : Analysis of variance for the studied characters in biparental progenies of two cotton crosses.

\begin{tabular}{|c|c|c|c|c|c|c|c|c|c|c|c|c|c|c|c|c|}
\hline crosses & $s .0 . \mathrm{V}$ & $d f$ & F.F.N & D.F.F & G.P.D & B.M.P & $\begin{array}{l}\text { B.W } \\
\text { (g) }\end{array}$ & $\begin{array}{l}\text { S.C.Y } \\
\text { (g) }\end{array}$ & L.Y (g) & L.P \% & S.I(g) & L.I (g) & F.F. & F.S. & F.L. & U.R. \\
\hline \multirow{5}{*}{ Cross I } & Replication & 2 & 0.519 & 3.562 & 2.771 & 0.255 & 0.070 & 9.5 & 1.10 & 0.090 & 0.178 & 0.089 & 0.044 & 0.029 & 0.192 & 0.482 \\
\hline & crosses & 31 & $1.405^{\star \prime}$ & $71.68^{\star *}$ & $74.18^{\star \star}$ & $7.963^{* *}$ & $0.333^{\star *}$ & $821^{\star *}$ & $131.4^{\star \star}$ & $8.509^{* *}$ & $0.941^{* *}$ & $0.790^{\star *}$ & $0.164^{\star *}$ & $0.423^{*}$ & $2.744^{* *}$ & $1.732^{* \star}$ \\
\hline & male & 15 & $1.636^{\star *}$ & $\mid 99.61^{* \star}$ & * $94.10^{\star \star}$ & $10.92^{\star \star}$ & $0.416^{\star \star}$ & $1101.7^{\star *}$ & $\star 165.5^{\star \star}$ & $10.09^{\star *}$ & $1.144^{\star \star}$ & *1.031** & $0.195^{\star \star}$ & $1.437^{\star \star}$ & $3.919^{* *}$ & $2.636^{\star \star}$ \\
\hline & $\begin{array}{l}\text { Females in } \\
\text { males }\end{array}$ & 16 & $1.189^{* *}$ & $\star 45.48^{\star *}$ & *55 $50^{* *}$ & $5.193^{\star *}$ & $0.255^{\star}$ & $557.8^{* *}$ & $99.45^{\star \star}$ & $7.027^{\star \star}$ & $0.751^{* *}$ & $\star 0.564 * *$ & $0.135^{\star \star}$ & $\star 1.410^{\star \star}$ & $1.643^{* *}$ & 0.885 \\
\hline & error & 62 & 0.422 & 4.579 & 6.540 & 0.540 & 0.084 & 153.6 & 24.94 & 0.629 & 0.315 & 0.125 & 0.024 & 0.266 & 0.374 & 0.657 \\
\hline \multirow{5}{*}{ Cross II } & Replice & 2 & 0.161 & 1.568 & 3.938 & 1.896 & 0.124 & $935.2^{*}$ & $137.3^{*}$ & 0.625 & 0.004 & 0.178 & 0.028 & 0.076 & $1.809^{\star}$ & 6.166 \\
\hline & crosse & 31 & $4.268^{\star \star}$ & $41.35^{\star \star}$ & $66.91^{* \star}$ & $7.633^{\star *}$ & $0.261^{* *}$ & $932.7^{\star *}$ & $134.9^{\star \star}$ & $9.150^{\star *}$ & $2.012^{\star \star}$ & $0.983^{* \star}$ & $0.499^{\star \star}$ & $1.758^{\star \star}$ & 7.400 ** & $39.59^{\star *}$ \\
\hline & male & 15 & $7.565^{\star \star}$ & $58.87^{\star \star}$ & $100.7^{\star \star}$ & $10.17^{\star \star}$ & $0.361^{\star *}$ & $1080.4^{\star *}$ & * $158.4^{\star \star *}$ & $14.49^{\star \star}$ & $3.175^{\star \star}$ & $1.316^{\star \star}$ & $0.565^{\star \star}$ & $1.768^{\star \star *}$ & $7.844^{* *}$ & $57.99^{\star *}$ \\
\hline & $\begin{array}{l}\text { Females in } \\
\text { males }\end{array}$ & 16 & $1.177^{*}$ & $24.93^{\star *}$ & $3520 *$ & 5 & $0.168^{\star *}$ & $794.3^{* *}$ & $112.8^{\star \star}$ & $4.146^{* *}$ & Q $921 * *$ & * $0.671^{* \star}$ & $126 * *$ & ${ }^{*} 1.748^{\star *}$ & $6.984^{* *}$ & $22.34^{\star *}$ \\
\hline & error & 62 & 0.457 & 3.030 & 3.760 & 0.632 & 0.069 & 247 & 39.65 & 0.857 & 0.248 & 0.210 & 0.064 & 0.271 & 0.558 & 6.687 \\
\hline
\end{tabular}

*,** Significant at 0.05 and 0.01 probability levels, respectively. 
Abdel-Moneam, M.A. et al.

Table 2 : Intra class variability for the studied characters in Bip and $F_{3}$ generation of two cotton crosses.

\begin{tabular}{|c|c|c|c|c|c|c|c|c|c|c|c|c|c|c|c|}
\hline \multirow[b]{2}{*}{ Crosses } & \multirow[b]{2}{*}{ Pop. } & \multicolumn{4}{|c|}{ Earliness Characters } & \multicolumn{6}{|c|}{ Yield Characters } & \multicolumn{4}{|c|}{ Fiber Characters } \\
\hline & & F.F.N & D.F.F & G.P.D & B.M.P & B.W (g) & S.C.Y (g) & L.Y $(!$ & L.P $\%$ & S.I(g) & L.I (g) & F.F. & F.S. & F.L. & U.R. \\
\hline \multirow{2}{*}{ I } & Bip & 0.7691 & 0.3125 & 0.3969 & 0.3345 & 0.7354 & 0.5504 & 0.5509 & 0.3694 & 0.7797 & 0.6207 & $0.425 \varepsilon$ & 0.4377 & 0.4628 & 0.7999 \\
\hline & F3 & 0.6277 & 0.3742 & 0.3729 & 0.6710 & $\mid 0.7953$ & 0.5679 & 0.5532 & 0.4576 & 0.652 & 0.6014 & 0.148 & 0.4435 & & 0.2050 \\
\hline \multirow[b]{2}{*}{ II } & Bip & 0.4168 & 0.3126 & 0.2708 & 0.3853 & 0.7855 & 0.6907 & 0.7250 & 0.4362 & 0.579 & 0.658 & 0.40 & & & 0.4285 \\
\hline & F3 & 0.6578 & 0.1682 & 0.1611 & 0.5709 & 0.7030 & 0.7045 & 0.7477 & 0.296 & 0.5574 & $0.580 \varsigma$ & 0.221 & 0.238 & 0.12 & 0.4869 \\
\hline
\end{tabular}




\section{J. Plant Production, Mansoura Univ., Vol. 4 (9), September, 2013}

Table 3 : Means, standard error (SE), range, genotypic and phenotypic coefficients of variation (GCV and PCV) for the studied characters in different population in two cotton crosses.

\begin{tabular}{|c|c|c|c|c|c|c|c|c|c|}
\hline \multirow{2}{*}{ characters } & \multirow{2}{*}{ crosses } & \multicolumn{2}{|c|}{ Mean \pm SE } & \multicolumn{2}{|c|}{ range } & \multicolumn{2}{|c|}{ Gcv \% } & \multicolumn{2}{|c|}{ Pcv \% } \\
\hline & & bip & F3 & bip & F3 & bip & F3 & bip & F3 \\
\hline \multirow[b]{2}{*}{ F.F.N. } & 1 & $5.435 \pm 0.058$ & $5.736 \pm 0.056$ & $4-7$ & $4-8$ & 18.61 & 12.48 & 22.11 & 16.64 \\
\hline & II & $6.260 \pm 0.075$ & $6.361 \pm 0.057$ & $5-9$ & $5-9$ & 32.99 & 12.60 & 34.72 & 15.30 \\
\hline \multirow[b]{2}{*}{ D.F.F. } & $T$ & $67.73 \pm 0.287$ & $67.33 \pm 0.179$ & $62-78$ & $62-78$ & 10.90 & 4.55 & 11.35 & 4.84 \\
\hline & III & $66.60 \pm 0.218$ & $68.51 \pm 0.212$ & $62-78$ & $64-84$ & 8.11 & 6.87 & 8.52 & 7.26 \\
\hline \multirow[b]{2}{*}{ G.P.D. } & 1 & $117.3 \pm 0.31$ & $118.2 \pm 0.20$ & $110-130$ & $112-129$ & 6.89 & 2.91 & 7.22 & 3.10 \\
\hline & il & $116.9 \pm 0.27$ & $119.6 \pm 0.26$ & $111-129$ & $113-137$ & 5.65 & 4.79 & 5.89 & 4.99 \\
\hline \multirow[b]{2}{*}{ B.M.P. } & & $50.44 \pm 0.097$ & $51.95 \pm 0.067$ & $48-54$ & $50-55$ & 4.94 & 1.59 & 5.15 & 2.20 \\
\hline & II & $50.07 \pm 0.098$ & $51.13 \pm 0.073$ & $48-53$ & $47-55$ & 4.96 & 2.08 & 5.21 & 2.64 \\
\hline \multirow{2}{*}{$\begin{array}{c}\text { B.w } \\
\text { (g) }\end{array}$} & $T$ & $2.834 \pm 0.027$ & $2.944 \pm 0.022$ & $1.967-3.900$ & $2.03-4.53$ & 16.85 & 9.75 & 19.72 & 12.48 \\
\hline & III & $3.099 \pm 0.025$ & $3.188 \pm 0.026$ & $2.070-4.200$ & $2.10-4.57$ & 11.67 & 12.05 & 14.44 & 14.14 \\
\hline \multirow{2}{*}{$\begin{array}{c}\text { S.c.y } / p \\
(\mathrm{~g})\end{array}$} & 1 & $61.31 \pm 1.14$ & $47.06 \pm 0.951$ & $28.00-108.7$ & $12.1-96.8$ & 37.86 & 31.87 & 42.92 & 34.43 \\
\hline & II & $67.56 \pm 1.38$ & $67.80 \pm 1.19$ & $30.75-119.8$ & $22.75-126.1$ & 39.98 & 24.67 & 46.26 & 29.74 \\
\hline \multirow{2}{*}{$\begin{array}{c}\mathrm{L} . \mathrm{y} / \mathrm{p} \\
(\mathrm{g})\end{array}$} & $T$ & $24.34 \pm 0.457$ & $18.67 \pm 0.382$ & $10.42-45.21$ & $5.45-38.4$ & 40.95 & 32.05 & 45.80 & 34.83 \\
\hline & $\pi$ & $25.96 \pm 0.542$ & $25.89 \pm 0.451$ & $11.56-49.62$ & $8.8-44.8$ & 38.04 & 23.94 & 45.11 & 29.62 \\
\hline \multirow{2}{*}{$\begin{array}{l}\text { L.p } \\
\%\end{array}$} & 1 & $39.65 \pm 0.102$ & $39.44 \pm 0.085$ & $34.51-42.22$ & $30.98-42.73$ & 7.37 & 3.47 & 7.63 & 3.97 \\
\hline & III & $38.35 \pm 0.111$ & $38.17 \pm 0.107$ & $33.98-41.80$ & $31.52-42.79$ & 6.84 & 5.34 & 7.26 & 5.63 \\
\hline \multirow{2}{*}{$\begin{array}{l}\text { S.i } \\
\text { (g) }\end{array}$} & 1 & $9.397 \pm 0.048$ & $9.735 \pm 0.048$ & $7.800-11.80$ & $8-12.6$ & 8.11 & 6.59 & 10.07 & 8.38 \\
\hline & II & $10.78 \pm 0.058$ & $11.17 \pm 0.057$ & $9.00-13.00$ & $8.8-13.6$ & 11.37 & 8.16 & 12.27 & 8.73 \\
\hline \multirow{2}{*}{$\begin{array}{l}\text { L.I } \\
\text { (g) }\end{array}$} & 1 & $6.191 \pm 0.037$ & $6.350 \pm 0.035$ & $4.980-7.615$ & $4.04-7.86$ & 12.36 & 7.20 & 13.61 & 9.32 \\
\hline & II & $6.730 \pm 0.043$ & $6.897 \pm 0.040$ & $5.238-8.199$ & $4.68-8.18$ & 11.65 & 9.26 & 13.49 & 9.78 \\
\hline \multirow[b]{2}{*}{ F.F. } & 1 & $4.462 \pm 0.015$ & $4.413 \pm 0.019$ & $3.3-5.4$ & $4-5.4$ & 8.61 & 9.89 & 9.29 & 10.66 \\
\hline & II & $3.924 \pm 0.025$ & $4.107 \pm 0.020$ & $3.2-4.9$ & $3.3-5$ & 17.94 & 10.63 & 19.07 & 11.43 \\
\hline \multirow[b]{2}{*}{ F.S. } & $T$ & $10.13 \pm 0.044$ & $9.857 \pm 0.042$ & $8.5-11.4$ & $8-11.6$ & 12.19 & 7.66 & 13.21 & 9.00 \\
\hline & II & $10.10 \pm 0.046$ & $10.04 \pm 0.041$ & $8.4-11.6$ & $8.2-11.3$ & 13.89 & 8.44 & 14.81 & 9.00 \\
\hline \multirow[b]{2}{*}{ F.I. } & i & $32.02 \pm 0.062$ & $31.62 \pm 0.072$ & $28.9-34$ & $28-33.90$ & 4.06 & 6.86 & 4.49 & 8.46 \\
\hline & $\pi$ & $32.69 \pm 0.091$ & $32.87 \pm 0.105$ & $28.6-35.6$ & $28.4-36.7$ & 8.95 & 7.18 & 9.24 & 7.39 \\
\hline \multirow[b]{2}{*}{ U.R. } & 1 & $85.96 \pm 0.067$ & $85.30 \pm 0.134$ & $80.3-87.9$ & $73.7-91.4$ & 1.26 & 3.30 & 1.57 & 3.42 \\
\hline & II & $85.98 \pm 0.229$ & $85.68 \pm 0.182$ & $75.1-92.7$ & $69.8-92.9$ & 5.67 & 8.77 & 6.42 & 12.11 \\
\hline
\end{tabular}


Abdel-Moneam, M.A. et al.

Table 4 : Assessment of additive (A), dominance (D), genetic (G), environmental (E) variances, degree of dominance $\sqrt{D} / A$ and heritability in broad $\left(H^{2} b \%\right)$ and narrow sense $\left(H^{2} n \%\right)$ for the studied characters in different populations in two cotton crosses.

\begin{tabular}{|c|c|c|c|c|c|c|c|c|c|c|}
\hline $\begin{array}{l}\text { Parameters } \\
\text { Characters }\end{array}$ & Crosses & Pop. & $\sigma^{2} A$ & $\sigma^{2} D$ & $\sigma^{2} E$ & $\sigma^{2} G$ & $\sigma^{2} \mathrm{Ph}$ & $\sqrt{ } \mathrm{D} / \mathrm{A}$ & $\mathrm{H}^{2} \mathrm{~b} \%$ & $\mathbf{H}^{2} \mathbf{n} \%$ \\
\hline \multirow{4}{*}{ F.F.N. } & \multirow[b]{2}{*}{1} & bip & 0.298 & 0.724 & 0.422 & 1.023 & 1.444 & 1.559 & 70.80 & 20.64 \\
\hline & & $\mathrm{F}_{3}$ & 0.674 & 0.04 & 0.399 & 0.513 & 0.912 & 0.244 & 56.26 & 55.43 \\
\hline & \multirow{2}{*}{$\|$} & bip & 4.259 & -3.299 & 0.457 & 4.259 & 4.716 & 0.880 & 90.30 & 90.30 \\
\hline & & $F_{3}$ & 0.441 & 1.663 & 0.305 & 0.642 & 0.948 & 1.942 & 67.77 & 34.88 \\
\hline \multirow{4}{*}{ D.F.F. } & \multirow[b]{2}{*}{1} & bip & 36.09 & 18.45 & 4.579 & 54.54 & 59.12 & 0.715 & 92.25 & 61.04 \\
\hline & & $F_{3}$ & 12.52 & -7.101 & 1.236 & 9.388 & 10.62 & 0.753 & 88.36 & 88.36 \\
\hline & \multirow{2}{*}{ ॥ } & bip & 22.63 & 6.566 & 3.030 & 29.20 & 32.23 & 0.539 & 90.60 & 70.22 \\
\hline & & $F_{3}$ & 29.55 & -61.90 & 2.555 & 22.16 & 24.72 & 1.447 & 89.66 & 89.66 \\
\hline \multirow{4}{*}{ G.P.D. } & \multirow{2}{*}{ I } & bip & 25.73 & 39.55 & 6.540 & 65.28 & 71.82 & 1.240 & 90.89 & 35.83 \\
\hline & & $F_{3}$ & 15.80 & -9.341 & 1.569 & 11.85 & 13.42 & 0.769 & 88.31 & 88.31 \\
\hline & \multirow{2}{*}{ II } & bip & 43.70 & -1.780 & 3.760 & 43.70 & 47.46 & 0.202 & 92.08 & 92.08 \\
\hline & & $F_{3}$ & 43.72 & -84.78 & 2.847 & 32.79 & 35.64 & 1.392 & 92.01 & 92.01 \\
\hline \multirow{4}{*}{ B.M.P. } & \multirow{2}{*}{ I } & bip & 3.818 & 2.386 & 0.540 & 6.203 & 6.743 & 0.790 & 91.99 & 56.61 \\
\hline & & $F_{3}$ & 0.803 & 0.449 & 0.619 & 0.686 & 1.305 & 0.748 & 52.58 & 46.12 \\
\hline & \multirow{2}{*}{$\|$} & bip & 3.276 & 2.888 & 0.632 & 6.164 & 6.796 & 0.939 & 90.69 & 48.20 \\
\hline & & $\mathrm{F}_{3}$ & 1.513 & -1.587 & 0.694 & 1.134 & 1.829 & 1.024 & 62.03 & 62.03 \\
\hline
\end{tabular}




\section{J. Plant Production, Mansoura Univ., Vol. 4 (9), September, 2013}

Cont4

\begin{tabular}{|c|c|c|c|c|c|c|c|c|c|c|}
\hline \multirow{4}{*}{$\begin{array}{l}\text { B.w } \\
(\mathrm{g})\end{array}$} & \multirow{2}{*}{1} & bip & 0.107 & 0.121 & 0.084 & 0.228 & 0.312 & 1.065 & 73.04 & 34.24 \\
\hline & & $F_{3}$ & 0.0005 & 0.437 & 0.052 & 0.082 & 0.135 & 27.14 & 61.08 & 0.330 \\
\hline & \multirow{2}{*}{$\|$} & bip & 0.129 & 0.002 & 0.069 & 0.131 & 0.200 & 0.131 & 65.32 & 64.23 \\
\hline & & $F_{3}$ & 0.045 & 0.607 & 0.056 & 0.147 & 0.203 & 3.677 & 72.53 & 16.56 \\
\hline \multirow{4}{*}{$\begin{array}{c}\text { S.c.y } / p \\
\text { (g) }\end{array}$} & \multirow{2}{*}{1} & bip & 362.6 & 176.2 & 153.6 & 538.9 & 692.5 & 0.697 & 77.82 & 52.37 \\
\hline & & $\mathrm{F}_{3}$ & 153.7 & 585.2 & 37.51 & 225 & 262.5 & 1.951 & 85.71 & 43.92 \\
\hline & \multirow{2}{*}{$\|$} & bip & 190.7 & 539 & 247 & 729.7 & 976.7 & 1.681 & 74.71 & 19.53 \\
\hline & & $F_{3}$ & 107.6 & 1062 & 126.8 & 279.8 & 406.7 & 3.142 & 68.81 & 19.84 \\
\hline \multirow{4}{*}{$\begin{array}{l}\text { L.y /p } \\
\text { (g) }\end{array}$} & \multirow{2}{*}{1} & bip & $\begin{array}{l}44.08 \\
\end{array}$ & 55.27 & 24.94 & 99.34 & $\begin{array}{l}124.3 \\
\end{array}$ & 1.120 & 79.93 & 35.46 \\
\hline & & $F_{3}$ & 27.81 & 79.71 & 6.473 & 35.80 & 42.28 & 1.693 & 84.69 & 49.33 \\
\hline & \multirow{2}{*}{ ॥ } & bip & 30.41 & 67.13 & 39.65 & 97.54 & 137.2 & 1.486 & 71.10 & 22.17 \\
\hline & & $F_{3}$ & 8.134 & 172.4 & 20.40 & 38.42 & 58.82 & 4.603 & 65.32 & 10.37 \\
\hline \multirow{4}{*}{$\begin{array}{l}\text { L.p } \\
\%\end{array}$} & \multirow{2}{*}{1} & bip & 2.041 & 6.489 & 0.630 & 8.530 & 9.160 & 1.783 & 93.13 & 22.28 \\
\hline & & $F_{3}$ & 2.504 & -1.957 & 0.572 & 1.878 & 2.450 & 0.884 & 76.67 & 76.67 \\
\hline & $\|$ & bip & 6.893 & -2.508 & 0.857 & 6.893 & 7.750 & 0.603 & 88.94 & 88.94 \\
\hline & $\pi$ & $F_{3}$ & 5.539 & -6.906 & 0.461 & 4.154 & 4.616 & 1.117 & 90.00 & 90.00 \\
\hline \multirow{4}{*}{$\begin{array}{l}\text { S.i } \\
\text { (g) }\end{array}$} & \multirow{2}{*}{1} & bip & 0.262 & 0.319 & 0.315 & 0.581 & 0.896 & 1.102 & 64.87 & 29.28 \\
\hline & & $F_{3}$ & 0.375 & 0.692 & 0.254 & 0.411 & 0.665 & 1.358 & 61.83 & 42.32 \\
\hline & & bip & 1.503 & -0.605 & 0.248 & 1.503 & 1.751 & 0.635 & 85.82 & 85.82 \\
\hline & 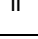 & $F_{3}$ & 0.577 & 2.126 & 0.121 & 0.831 & 0.952 & 1.919 & 87.33 & 45.45 \\
\hline \multirow{4}{*}{$\begin{array}{l}\text { L.I } \\
\text { (g) }\end{array}$} & \multirow{2}{*}{1} & bip & 0.311 & 0.274 & 0.125 & 0.585 & 0.710 & 0.938 & 82.42 & 43.84 \\
\hline & & $F_{3}$ & 0.279 & -0.024 & 0.141 & 0.209 & 0.351 & 0.293 & 59.65 & 59.65 \\
\hline & \multirow{2}{*}{$\|$} & bip & 0.43 & 0.185 & 0.210 & 0.615 & 0.825 & 0.656 & 74.55 & 52.14 \\
\hline & & $F_{3}$ & 0.219 & 1.302 & 0.047 & 0.408 & 0.455 & 2.441 & 89.68 & 36.02 \\
\hline
\end{tabular}


Abdel-Moneam, M.A. et al.

\section{Cont 4}

\begin{tabular}{|c|c|c|c|c|c|c|c|c|c|c|}
\hline \multirow{4}{*}{ F.F. } & \multirow{2}{*}{ I } & bip & 0.040 & 0.108 & 0.024 & 0.148 & 0.172 & 1.65 & 85.81 & 23.02 \\
\hline & & $F_{3}$ & 0.254 & -0.631 & 0.030 & 0.191 & 0.221 & 1.575 & 86.19 & 86.19 \\
\hline & \multirow{2}{*}{ II } & bip & 0.086 & 0.409 & 0.064 & 0.495 & 0.560 & 2.177 & 88.49 & 15.42 \\
\hline & & $F_{3}$ & 0.254 & -0.534 & 0.030 & 0.191 & 0.220 & 1.449 & 86.46 & 86.46 \\
\hline \multirow{4}{*}{ F.S. } & \multirow{2}{*}{ I } & bip & 0.018 & 1.507 & 0.266 & 1.525 & 1.791 & 9.25 & 85.13 & 0.98 \\
\hline & & $F_{3}$ & 0.760 & -1.395 & 0.218 & 0.570 & 0.788 & 1.355 & 72.36 & 72.36 \\
\hline & & bip & 0.014 & 1.956 & 0.271 & 1.970 & 2.240 & 11.99 & 87.92 & 0.61 \\
\hline & $\|$ & $F_{3}$ & 0.957 & -1.786 & 0.099 & 0.718 & 0.817 & 1.366 & 87.91 & 87.91 \\
\hline \multirow{4}{*}{ F.I. } & \multirow{2}{*}{1} & bip & 1.517 & 0.174 & 0.374 & 1.692 & 2.066 & 0.339 & 81.88 & 73.44 \\
\hline & & $F_{3}$ & 6.284 & -30.08 & 2.436 & 4.713 & 7.149 & 2.188 & 65.92 & 65.92 \\
\hline & & bip & 0.573 & 7.995 & 0.558 & 8.568 & 9.126 & 3.735 & 93.88 & 6.28 \\
\hline & $\|$ & $F_{3}$ & 7.424 & -14.29 & 0.331 & 5.568 & 5.899 & 1.387 & 94.39 & 94.39 \\
\hline \multirow{4}{*}{ U.R. } & \multirow[b]{2}{*}{ I } & bip & 1.167 & -0.863 & 0.657 & 1.167 & 1.824 & 0.860 & 63.97 & 63.97 \\
\hline & & $F_{3}$ & 10.56 & -17.33 & 0.608 & 7.920 & 8.529 & 1.281 & 92.86 & 92.86 \\
\hline & \multirow{2}{*}{ II } & bip & 23.77 & -2.89 & 6.687 & 23.77 & 30.45 & 0.349 & 78.04 & 78.04 \\
\hline & & $\mathrm{F}_{3}$ & 75.28 & -523.2 & 51.27 & 56.46 & 107.7 & 2.636 & 52.41 & 52.41 \\
\hline
\end{tabular}

